\title{
Cultivation of mushrooms for production of food biofortified with lithium
}

\author{
Mirosław Mleczek $^{1} \cdot$ Marek Siwulski $^{2} \cdot$ Piotr Rzymski $^{3} \cdot$ Sylwia Budzyńska $^{1} \cdot$ \\ Monika Gąsecka $^{1} \cdot$ Pavel Kalač $^{4} \cdot$ Przemysław Niedzielski $^{5}$
}

Received: 2 September 2016 / Revised: 26 October 2016 / Accepted: 12 November 2016 / Published online: 26 November 2016

(C) The Author(s) 2016. This article is published with open access at Springerlink.com

\begin{abstract}
It has recently been suggested that food fortification with $\mathrm{Li}$ is worth serious consideration as a strategy to support psychiatric treatment and decrease violent behaviors in the general population. Therefore, the present study developed the cultivation of three commercially important mushroom species, Ganoderma lucidum, Pleurotus eryngii and Pleurotus ostreatus, on substrates enriched with $\mathrm{Li}(0.25-1.0 \mathrm{mM})$ in the form of acetate or carbonate. The growth of the mycelium colony, production of fruiting bodies and accumulation of $\mathrm{Li}$ were evaluated. Analysis of $\mathrm{Li}$ was performed using an optical emission spectrometry with excitation by inductively coupled plasma using an Agilent 5100 ICP-OES spectrometer. As found, $\mathrm{Li}_{2} \mathrm{CO}_{3}$ was a more bioavailable form although it had a greater adverse effect on mushroom growth. Substrate supplementation with $\mathrm{CH}_{3} \mathrm{COOLi}$ resulted in lower or no growth retardation but decreased uptake of $\mathrm{Li}$. The most promising results were obtained for $G$. lucidum, which accumulated up to $73.58 \pm 10.87\left(\mathrm{Li}_{2} \mathrm{CO}_{3}\right)$ and $25.59 \pm 9.98\left(\mathrm{CH}_{3} \mathrm{COOLi}\right)$ $\mathrm{mg} \mathrm{Li} \mathrm{kg}^{-1}$ dry mass. Given the popularity of the
\end{abstract}

Mirosław Mleczek

mirekmm@up.poznan.pl

1 Department of Chemistry, Poznan University of Life Sciences, Poznan, Poland

2 Department of Vegetable Crops, Poznan University of Life Sciences, Poznan, Poland

3 Department of Environmental Medicine, Poznan University of Medical Sciences, Poznan, Poland

4 Department of Applied Chemistry, Faculty of Agriculture, University of South Bohemia, Ceske Budejovice, Czech Republic

5 Faculty of Chemistry, Adam Mickiewicz University in Poznan, Poznan, Poland investigated mushroom species in various cultures as food or alternative medicines, their Li-biofortified forms could potentially find social acceptance. The concentrations of $\mathrm{Li}$ accumulated in fruiting bodies were not high enough for application in psychiatric treatments but could potentially support the daily intake of $\mathrm{Li}$ for behavior modification or health beneficiary purposes. Further studies are necessary to fully investigate the safety implications of Li-enriched mushrooms for humans.

Keywords Lithium · Biofortification · Ganoderma lucidum $\cdot$ Pleurotus eryngii $\cdot$ Pleurotus ostreatus

\section{Introduction}

Mood disorders, including bipolar disorder, represent an important category of mental illnesses, whose prevalence is generally increasing in developed countries. Over the years, a number of psychopharmacological agents have been introduced, with lithium ( $\mathrm{Li}$ ) cation being one of the most promising and effective, primarily in the recovery of bipolar affective disorder [1]. However, its potential therapeutic application spectra are much wider with evidence supporting its use in the treatment of unipolar depression [2], acute mania and its prophylactic [3, 4], or reduction in suicidal and aggressiveness rates in affective disorders [5, 6] and conduct disorder [7]. It is also speculated whether Li could be used in treating neurodegenerative disorders including Alzheimer's disease and, importantly, its prevention [8]. Apart from a purely applied medical use, some authors have suggested that nutritional intake of $\mathrm{Li}$ could be potentially beneficial for mood stabilization and may lead to a decrease in aggressive behavior in the general population [9-11]. 
Unlike many traditional psychopharmacological compounds, Li does not bind to a cellular receptor but modifies the intracellular second messenger system. Its main postulated mechanisms of action are based on effects excreted on inositol monophosphatase (IMPase) within the phosphatidylinositol (PI) signaling pathway and the protein kinase glycogen synthase kinase $3 \beta$ (GSK-3 $\beta$ ) [12]. Calcium carbonate taken orally as pills is the most often applied form [13]. However, Li may also be supplied in relatively low doses with diet, particularly through consumption of grains and vegetables, and also in some areas with drinking water [14]. Interestingly, decreased levels of dietary intake of $\mathrm{Li}$ have been potentially linked to the prevalence of manicdepressive psychosis [15] and rates of suicides, homicides, or even the arrest rates for drug use and other crimes [16]. Altogether, this supports the hypothesis that Li consumption with food may have prophylactic value in the primary prevention of mood disorder [17]. However, most food products are poor in Li [14], while the use of Li-containing pharmaceuticals is likely to be socially linked with serious mental illness [10].

Information on natural $\mathrm{Li}$ content in mushrooms is scarce. Its mean concentration reported for wild-growing mushrooms collected from different locations in Hungary and Italy amounted only to 0.19 and $0.25 \mathrm{mg} \mathrm{kg}^{-1}$ dry weight, respectively $[18,19]$, while in cultivated Pleurotus mushrooms, Li content was found to be below detection limit [20]. Recently, however, the concept of mushrooms enriched in various elements such as selenium, zinc or copper for use as functional foods has been developed [21-23]. Mushrooms are a potentially rich target of such a biofortification strategy owing to their ability to accumulate various elements present in the overgrown substrates [24]. They also represent traditional natural products used widely in various cuisines [25], and some species are well recognized for their potential medicinal use [26]. Moreover, commercial cultivation of mushrooms can be made cost- and time-effective [27]. And Li fortification of food has recently been highlighted as worth serious consideration [9]. Li-enriched mushrooms may represent an interesting and more socially acceptable alternative in dietary supplementation of this element for various health beneficiary purposes. Nevertheless, to date the bioenrichment of mushrooms with Li has largely been ignored-only one study assessed the ability of $P$. ostreatus to accumulate $\mathrm{Li}$ added to the cultivation substrate in the form of $\mathrm{LiCl}$ [28]. As reported, the supplementation significantly increased $\mathrm{Li}$ concentrations in fruiting bodies (reaching maximally over $150 \mathrm{mg} \mathrm{kg}^{-1}$ ) and did not alter crude protein content.

The aim of the present study was to evaluate the feasibility of mushroom species: G. lucidum (known as "Chinese Lingzhi"), $P$. eryngii and P. ostreatus (known as "king oyster" and "oyster" mushroom, respectively) for bioenrichment with $\mathrm{Li}$ in the form of carbonate and acetate. All three mushrooms are commercially important species, valued for their nutritional properties, with various medicinal uses reported in in vitro and in vivo studies [29, 30]. Our study highlights that they may additionally represent promising carriers of dietary Li.

\section{Materials and methods}

\section{Experimental design}

The substrate for $P$. ostreatus was prepared from a mixture of beech and alder sawdust (1:1 vol.), additionally supplemented with wheat bran in the amount of $20 \%$, wheat straw chaw $10 \%$, corn flour $5 \%$, soybean meal $3 \%$, chalk $1 \%$ and gypsum $1 \%$ in relation to the substrate weight. For P. eryngii and G. lucidum, a mixture of beech and alder sawdust was also used, but the following supplements were added: wheat bran $20 \%$, corn flour $5 \%$, soybean meal $3 \%$, sucrose $1 \%$ and gypsum $1 \%$. The mixtures were moistened to $45 \%$ of water content using distilled water, placed in polypropylene bags and sterilized at $121{ }^{\circ} \mathrm{C}$ for $1 \mathrm{~h}$. Li was added to the substrate in the form of solutions prepared from $\mathrm{Li}_{2} \mathrm{CO}_{3}$ or $\mathrm{CH}_{3} \mathrm{COOLi}$ (Sigma-Aldrich) in concentrations of 0.25 , $0.5,0.75$ and $1.0 \mathrm{mM}$. The moisture of the substrates after $\mathrm{Li}$ addition was $60 \%$. The substrates were mixed with grain spawn of tested mushroom species (5\% of substrate weight) and placed in $17 \times 25 \mathrm{~cm}$ polypropylene foil bags with a filter (P. ostreatus and G. lucidum) or in 1-L polypropylene bottles with a cellulose filter type 338 (Munktell, Bärenstein, Germany) with a basic weight of $84 \mathrm{~g} / \mathrm{m}^{2}$ and typical retention of $12-15 \mu \mathrm{m}$ (P. eryngii).

Sterile Petri dishes for mycelium growth testing were used. The dishes were filled with the examined substrates after which three grains of mushroom spawn were placed in their central part. Incubation was conducted at $25{ }^{\circ} \mathrm{C}$ for 9 days. After that time, the diameter of the mycelium colony was noted.

The incubation in bags and bottles was conducted at $25{ }^{\circ} \mathrm{C}$ and $80-85 \%$ relative humidity until the substrate became completely covered with mycelium. Next, the bottles with removed covers and bags with the top part of the foil cut off were placed in a cultivation chamber. For fructification, humidity was maintained at $85-90 \%$ and temperature at $16 \pm 1{ }^{\circ} \mathrm{C}$ for $P$. ostreatus and P. eryngii and at $25 \pm 1{ }^{\circ} \mathrm{C}$ for $G$. lucidum. The cultivation chamber was illuminated with fluorescent light of $500 \mathrm{~lx}$ intensity for $12 \mathrm{~h}$ a day and aerated to maintain $\mathrm{CO}_{2}$ concentration below $1000 \mathrm{ppm}$. Fruiting bodies of $P$. eryngii and $P$. ostreatus were harvested successively as they matured. Yield included fruiting bodies with stipes from one flush of yielding for $P$. eryngii and two flushes for P. ostreatus. 
Fruiting bodies of G. lucidum were harvested at once 45 days after inoculation.

Mushroom fruiting bodies were dried in an electric drier SLW 53 STD (Pol-Eko, Wodzisław Śląski, Poland) at $50{ }^{\circ} \mathrm{C}$ for $48 \mathrm{~h}$, weighted and ground for $0.5 \mathrm{~min}$ in a Cutting Boll Mill 200 (Retsch GmbH, Haan, Germany). The powdered samples were treated in the extraction. The method described above was similar to that presented in the author's previous studies [21].

\section{Instrument}

An optical emission spectrometer with excitation by inductively coupled plasma Agilent 5100 ICP-OES (Agilent, USA) was used in radial plasma observation mode (wavelength $670.783 \mathrm{~nm}$, radio frequency (RF) power $1.2 \mathrm{~kW}$, nebulizer gas flow $0.7 \mathrm{~L} \mathrm{~min}^{-1}$, auxiliary gas flow $1.0 \mathrm{~L} \mathrm{~min}^{-1}$, plasma gas flow $12.0 \mathrm{~L} \mathrm{~min}^{-1}$, viewing height $8 \mathrm{~mm}$, signal accusation time $5 \mathrm{~s}$ for three replicates). The commercial analytical standard (Romil, England) was used for analysis. The detection limits were determined on the level of $0.01 \mathrm{mg} \mathrm{kg}^{-1}$ dry weight (DW as three-sigma criteria). The uncertainty for total analytical procedure (including sample preparation) was at the level of $20 \%$. Results recovery of standard addition (used due to a lack of certified standard materials for phosphoric acid extraction) was 80-120\%.

\section{Procedure}

Mushrooms were dried at $50 \pm 2{ }^{\circ} \mathrm{C}$ for $24 \mathrm{~h}$ and at $80 \pm 2{ }^{\circ} \mathrm{C}$ for $8 \mathrm{~h}$ in an electric oven (SLW $53 \mathrm{STD}$, Pol-Eko, Wodzisław Śląski, Poland) to dry matter and then ground in a laboratory Cutting Boll Mill PM 200 (Retsch GmbH, Haan, Germany). Accurately weighed $0.300 \pm 0.001 \mathrm{~g}$ of a dry sample of mushroom was ultrasonically extracted by phosphoric acid $1 \mathrm{~mol} \mathrm{~L}^{-1}$ solution (Honeywell, USA). After extraction, samples were filtered and diluted with water to a final volume of $15.0 \mathrm{~mL}$. Each of the samples was analyzed in triplicate using the whole sample preparation procedure.

\section{Statistical analysis}

The results were analyzed using STATISTICA 12.0 software (StatSoft, USA). One-way analysis of variance (ANOVA) followed by the post hoc Tukey's HSD test was applied to investigate the differences in $\mathrm{Li}$ accumulation and mushroom growth between the studied species. Correlations between $\mathrm{Li}$ content in fruiting bodies and their biomass were assessed with the Pearson correlation coefficient. $P<0.05$ was considered as statistically significant.

\section{Results}

\section{The effect of Li on the mycelium colony}

The addition of $\mathrm{Li}_{2} \mathrm{CO}_{3}$ and $\mathrm{CH}_{3} \mathrm{COOLi}$ resulted in a distinctively different response of mycelium growth (Fig. 1). Higher levels of $\mathrm{Li}_{2} \mathrm{CO}_{3}(0.75$ and $1.0 \mathrm{mM}$ for P. eryngii and G. lucidum, and $\geq 0.5 \mathrm{mM}$ for $P$. ostreatus) significantly altered the mycelium colony growth (Fig. 1). In the presence of all concentrations of $\mathrm{CH}_{3} \mathrm{COOLi}$, mycelium of all three species developed intensively.

\section{The effect of Li on fruiting body morphology and biomass}

The characteristics of fruiting bodies obtained from Lienriched cultivation are collectively presented in Fig. 2. Most cultivation models did not induce any visible macroscopic alterations. P. eryngii did not grow on substrates supplemented initially with 0.75 and $1 \mathrm{mM}$ of $\mathrm{Li}_{2} \mathrm{CO}_{3}$, whereas fruiting bodies of $G$. lucidum were clearly deformed and lower in the presence of $1 \mathrm{mM}$ of $\mathrm{Li}_{2} \mathrm{CO}_{3}$ (Fig. 2).

The biomass of the collected fruit bodies depended more on mushroom species than on the form of $\mathrm{Li}$ used for supplementation (Fig. 3). Generally, the greatest biomass was produced by $P$. eryngii grown with $\mathrm{Li}_{2} \mathrm{CO}_{3}$ and $\mathrm{CH}_{3} \mathrm{COOLi}$ (mean for all concentrations was $96.0 \pm 1.2$ and $93.7 \pm 5.0 \mathrm{~g}$, respectively), while the lowest biomass was observed for P. ostreatus collected from the second flush of yielding $(37.6 \pm 7.6$ and $41.5 \pm 7.3 \mathrm{~g}$, respectively). Biomass of G. lucidum fruiting bodies, in turn, was generally comparable over different $\mathrm{CH}_{3} \mathrm{COOLi}$ concentrations and significantly affected by the highest level of $\mathrm{Li}_{2} \mathrm{CO}_{3}$ employed in this study. Similarly, $\mathrm{CH}_{3} \mathrm{COOLi}$ did not induce significant changes in the biomass of $P$. ostreatus from the first flush of yielding, contrary to $\mathrm{Li}_{2} \mathrm{CO}_{3}$ which decreased mushroom biomass at the greatest substrate concentrations ( 0.75 and $1 \mathrm{mM})$.

\section{Efficiency of lithium accumulation in mushroom species}

The form of Li used in the experiment was crucial in its uptake and accumulation in mushroom fruiting bodies (Fig. 4). Generally, the accumulated content increased over the initial Li concentration. In most cases, a greater mean content of $\mathrm{Li}$ was noted when substrates were supplemented with $\mathrm{Li}_{2} \mathrm{CO}_{3}$ than $\mathrm{CH}_{3} \mathrm{COOLi}$. It should, however, be noted that $P$. eryngii did not grow at higher $\mathrm{Li}_{2} \mathrm{CO}_{3}$ concentrations. The greatest mean content of $\mathrm{Li}$ was found for G. lucidum, exceeding $70 \mathrm{mg} \mathrm{kg}^{-1} \mathrm{dm}$ after the substrate was enriched with $1 \mathrm{mM}$ of $\mathrm{Li}$ as $\mathrm{Li}_{2} \mathrm{CO}_{3}$ and $25 \mathrm{mg} \mathrm{kg}^{-1}$ $\mathrm{dm}$ following the substrate supplementation with $1 \mathrm{mM}$ of 
Fig. 1 Characteristics of mycelium colony of the studied mushroom species
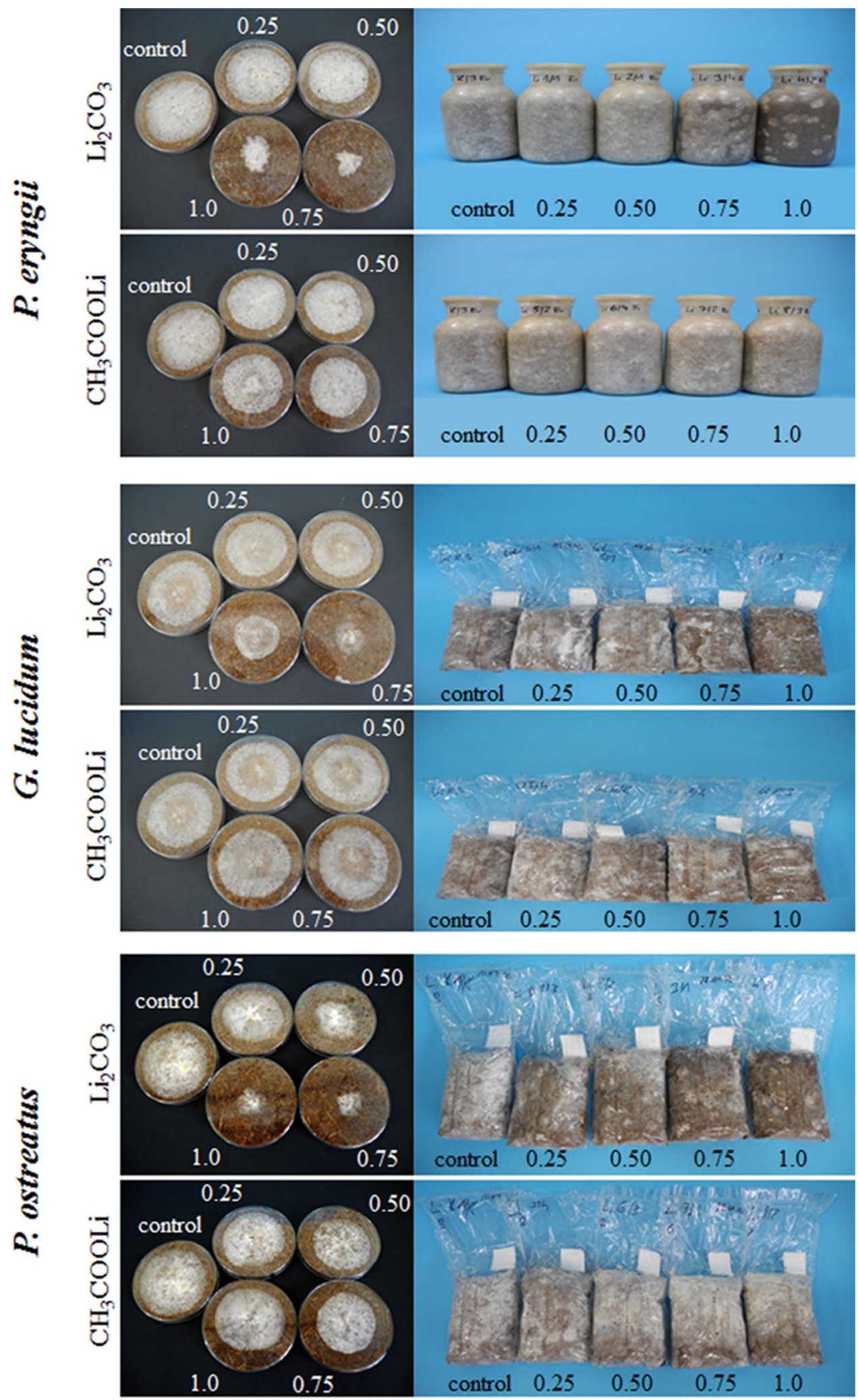

$\mathrm{Li}$ in the form of $\mathrm{CH}_{3} \mathrm{COOLi}$. The maximum accumulation for $P$. ostreatus first flush was $12.0 \mathrm{mg} \mathrm{kg}^{-1}\left(\mathrm{Li}_{2} \mathrm{CO}_{3}\right)$ and $8.3 \mathrm{mg} \mathrm{kg}^{-1}\left(\mathrm{CH}_{3} \mathrm{COOLi}\right)$ and $P$. ostreatus second flush $16.5 \mathrm{mg} \mathrm{kg}^{-1}\left(\mathrm{Li}_{2} \mathrm{CO}_{3}\right)$ and $5.3 \mathrm{mg} \mathrm{kg}^{-1}\left(\mathrm{CH}_{3} \mathrm{COOLi}\right)$, and for $P$. eryngii, it amounted to $10.9 \mathrm{mg} \mathrm{kg}^{-1}\left(\mathrm{Li}_{2} \mathrm{CO}_{3}\right)$ and $15.1 \mathrm{mg} \mathrm{kg}^{-1}\left(\mathrm{CH}_{3} \mathrm{COOLi}\right)$.

There was a significant negative correlation between Li concentrations in fruiting bodies of G. lucidum, $P$. 


\section{Pleurotus eryngii}

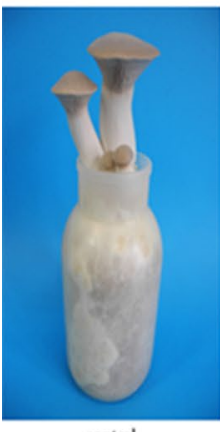

control

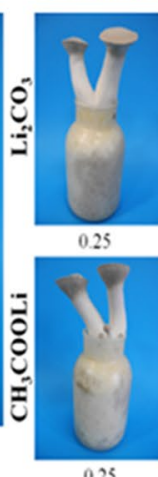

0.25
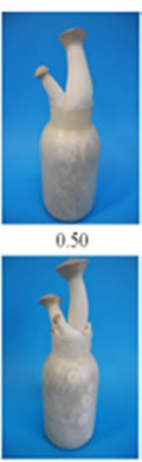

0.50
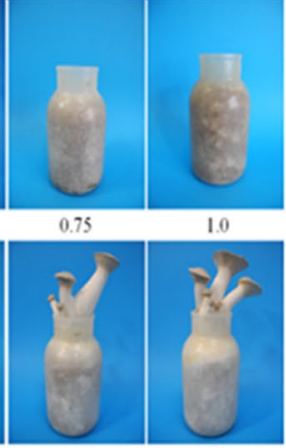

10

Pleurotus ostreatus 1st flush of yielding
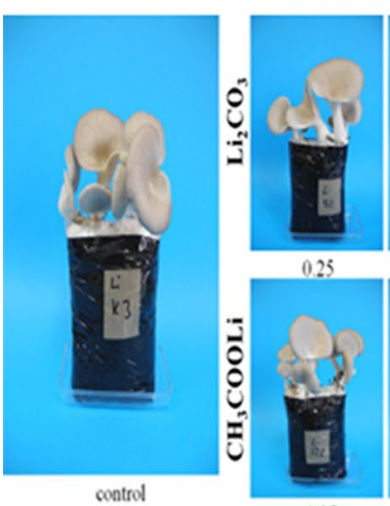

0.25
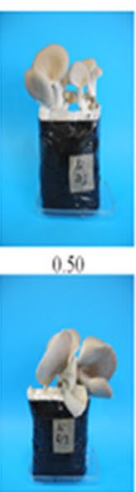

0.50

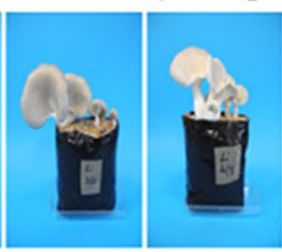

0.75

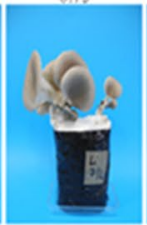

0.75

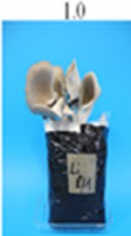

1.0
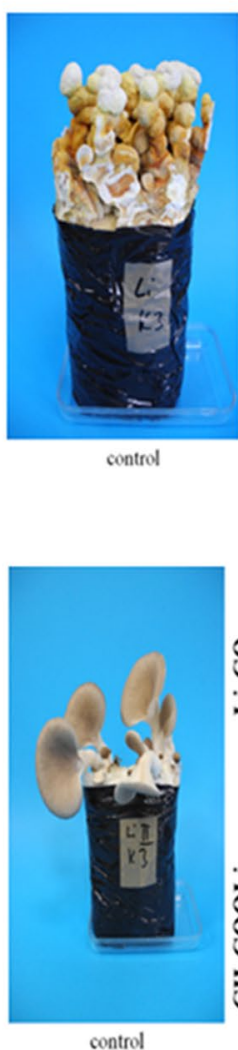

Ganodermalucidum

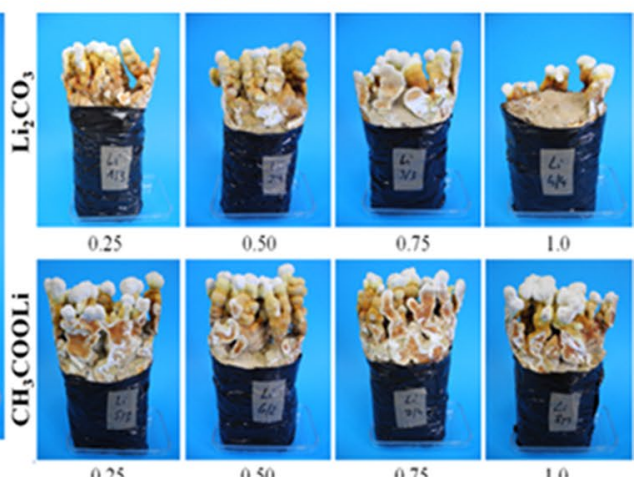

1.0

Fig. 2 Morphology of mushroom species growing on substrate enriched with lithium carbonate and lithium acetate

Pleurotus ostreatus 2 nd flush of yielding

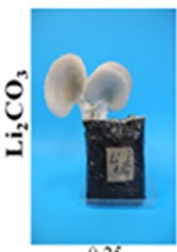

0.25
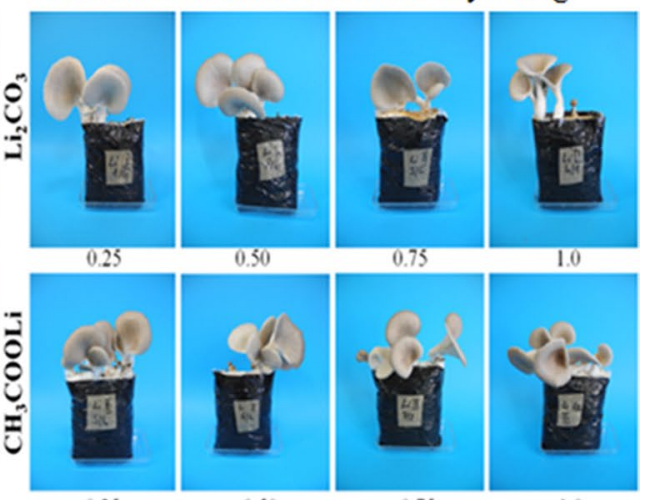

0.25

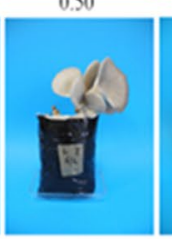

0.50

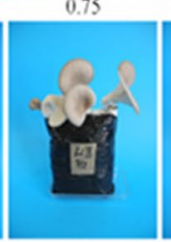

0.75

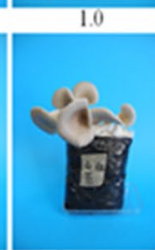

1.0

Fig. 3 Biomass (g) of mushroom species

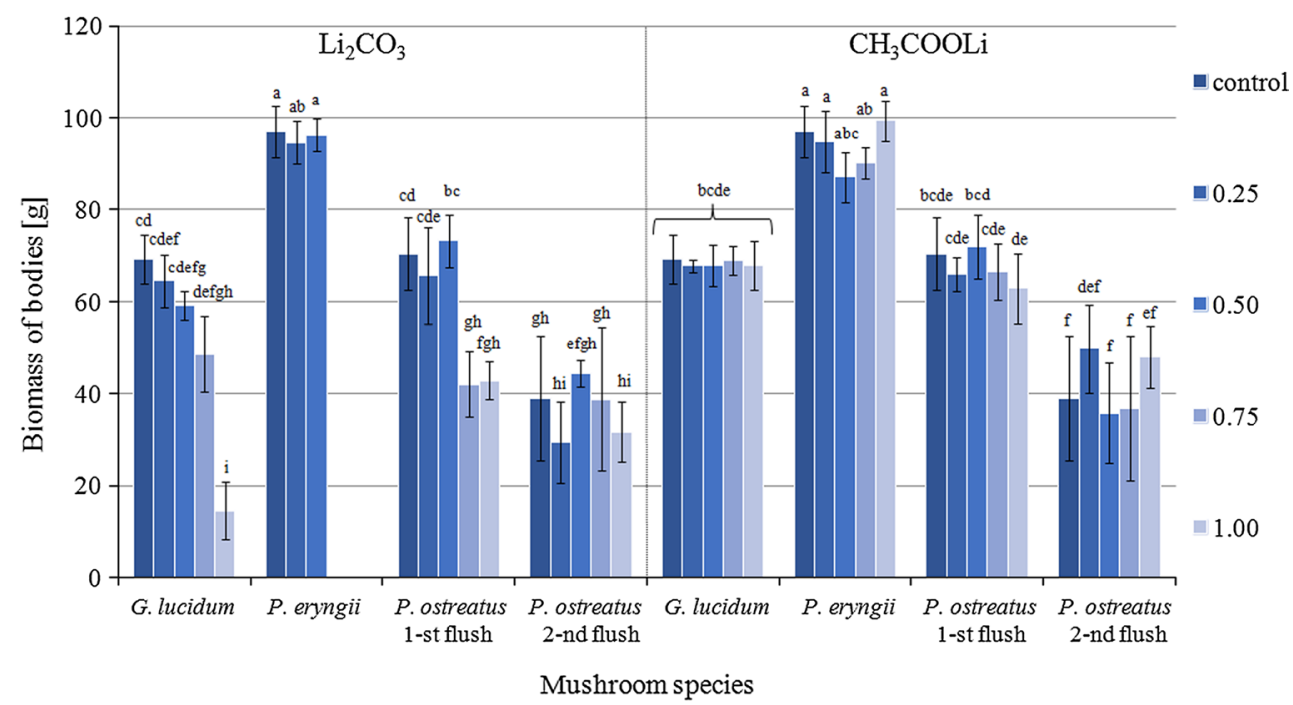

eryngii and $P$. ostreatus first flush of yielding in the presence of $\mathrm{Li}_{2} \mathrm{CO}_{3}$, and the biomass of their fruiting bodies $(r=-0.98, r=-0.76$ and $r=-0.93$, respectively; $p<0.05)$. No statistically significant correlations were found between these two parameters when mushrooms were grown in the presence of $\mathrm{CH}_{3} \mathrm{COOLi}$ and when $P$. ostreatus second flush of yielding was cultivated with substrates supplemented with $\mathrm{Li}_{2} \mathrm{CO}_{3}(p>0.05$ in all cases). 
Fig. 4 Content of $\mathrm{Li}$ (mg kg ${ }^{-1}$ dry matter) in fruit bodies of mushroom species

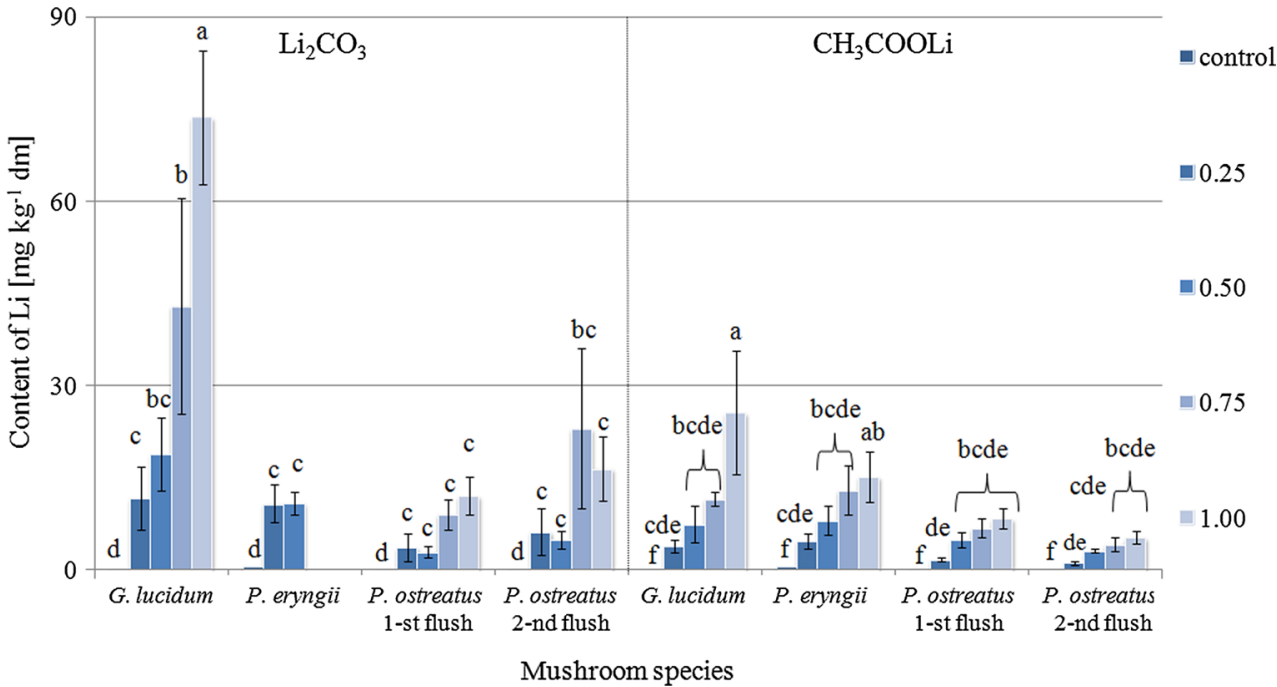

\section{Discussion and conclusions}

The bioenrichment of mushrooms during their cultivation process is becoming increasingly studied as a promising strategy to produce functional foods [22, 23, 31]. It has been suggested that nutritional intake of Li may be beneficial for health, particularly in the prevention or amelioration of neurological and psychiatric alteration [32, 33]. The present study demonstrates that in fact, some mushrooms species may easily uptake Li from the overgrown substrate and efficiently accumulate it in their fruiting bodies without a significant alteration of their growth and morphology.

Potential commercial application of Li-enriched mushrooms as a nutraceutical would require their cultivation to be cost-effective and efficient as regards produced biomass. An artificially increased content of various elements in cultivation substrate may largely affect the growth and appearance of mushrooms and result in increased cultivation expenses as well as a decrease in the attractiveness of the final product for potential consumers and a lower market value [22, 34]. As demonstrated, the cultivated species were generally more resistant to $\mathrm{Li}$ in the form of acetate and developed a greater mycelium colony and subsequently larger biomass of fruiting bodies. This is in line with results obtained by Nunes et al. [35] who compared the growth of various white-rot fungi on potato dextrose agar supplemented with different forms of $\mathrm{Li}$ : acetate, chloride, hydroxide, sulfate and carbonate. The latter was found to be the most toxic; in its presence, no mycelium growth was observed for most of the investigated species (including P. eryngii). It should be highlighted that all $\mathrm{Li}$ compounds employed by Nunes et al. [35] decreased mushroom growth several-fold (except for $P$. djamor) compared to the control. This largely discourages the employment of non-composted substrates in enrichment of mushrooms with $\mathrm{Li}$ as the bioavailability of this element may be too high and lead to toxic effects. Previous investigations by de Assunção et al. [28] indicated that $P$. ostreatus may be successfully cultivated on coffee husk substrate supplemented with $\mathrm{Li}$ chloride. Our study adds further evidence that solid substrates with $\mathrm{CH}_{3} \mathrm{COOLi}$ and $\mathrm{Li}_{2} \mathrm{CO}_{3}$ can also be used in bioenrichment of fruiting bodies.

Particularly promising results of the present study were obtained for G. lucidum. This species grew well on substrates supplemented with every concentration of $\mathrm{CH}_{3} \mathrm{COOLi}$, and in this case, maximal accumulation in fruiting bodies exceeded $25 \mathrm{mg} \mathrm{kg}^{-1}$ dry matter (DM). Although higher concentrations of $\mathrm{Li}_{2} \mathrm{CO}_{3}, 0.75$ and $1.0 \mathrm{mM}$, significantly decreased the biomass, the $\mathrm{Li}$ accumulation exceeded 40 and $60 \mathrm{mg} \mathrm{kg}^{-1}$ dry matter, respectively. The commercial application of Li-enriched $G$. lucidum may be additionally supported for the medicinal properties of this species, which have long been acknowledged [29, 36-38]. Considering that the market for G. lucidum is already worth over 2.5 billion US dollars [39], the commercial introduction of its Li-enriched form should not be troublesome. The safety of such a product should be first evaluated, preferably using both in vitro and in vivo models; its target group of potential consumers should be then clearly defined, presumably on the bases of randomized trials conducted on various populations.

The use of $\mathrm{Li}$ in the treatment of psychiatric disorders requires relatively high daily doses taken orally. These may even rise to as much as $600-1200 \mathrm{mg}$ of $\mathrm{Li}_{2} \mathrm{CO}_{3}$ taken daily in divided doses, which equates to $113-226 \mathrm{mg}$ of elemental $\mathrm{Li}$ [40]. Our study demonstrated that a single consumption of a meal containing $100 \mathrm{~g}$ of dried G. lucidum, P. ostreatus first flush, P. ostreatus second flush and 
P. eryngii would constitute 7.4, 1.2, 1.6 and $1.9 \mathrm{mg}$ of $\mathrm{Li}$ intake if substrates were fortified with $1 \mathrm{mM}$ of $\mathrm{Li}_{2} \mathrm{CO}_{3}$ (or $0.5 \mathrm{mM}$ in case of $P$. eryngii). To compare, consumption of the same amount of mushrooms grown on substrates supplemented with $1 \mathrm{mM}$ of $\mathrm{CH}_{3} \mathrm{COOLi}$ would equal a $\mathrm{Li}$ intake of $2.6 \mathrm{mg}$ (G. lucidum), $0.8 \mathrm{mg}$ (P. ostreatus first flush), $0.5 \mathrm{mg}$ (P. ostreatus second flush) and $1.5 \mathrm{mg}(P$. eryngii). These calculations, however, do not include the partial loss, which may occur during mushroom processing, e.g., washing or cooking [25, 41]. Moreover, they do not consider the absorption kinetics in the gastrointestinal tract, although in vitro bioavailability of Li from mushrooms was reported to be very high, far surpassing that of the pharmaceutical drug containing $\mathrm{Li}_{2} \mathrm{CO}_{3}$ [28]. Altogether, it is more likely that $\mathrm{Li}$-enriched mushrooms such as G. lucidum, P. ostreatus and $P$. eryngii may find a practical application in prophylactics of mood alterations rather than in psychiatric treatment. Importantly, moderately increased Li consumption may also be beneficial in stabilizing the mood of former alcoholics and drug users [32, 42]. Such food products could ensure an adequate dietary intake of $\mathrm{Li}$ for the purpose of decreasing the frequency of aggression and violence, as supported by observations that suicides, anxiety and homicides may be linked to low serum Li levels [43-45]. To maintain its physiological levels, the provisional recommended dietary allowance for $\mathrm{Li}$ in adults has been proposed at the level of $1 \mathrm{mg}$ for a $70-\mathrm{kg}$ adult, although tenfold higher doses were not reported to induce any adverse health effects [14]. To meet the nutritional demand for $\mathrm{Li}$, some authors have recently suggested that cereal grain products be fortified with $\mathrm{Li}$, or $\mathrm{Li}$ be added to dietary supplements [9]. Mushrooms may be an interesting or even superior option in this regard if one considers their popularity in different cuisines, their traditional use in various cultures for the maintenance of health and disease prevention and their social acceptance as foodstuffs [26]. All three species investigated in our study could serve as a source of moderately increased dietary $\mathrm{Li}$ at doses far below those reported to be toxic for humans [14]. On the other hand, the present study demonstrated relatively high variations of $\mathrm{Li}$ content in mushroom fruiting bodies as presented by SD values for each $\mathrm{Li}$ concentration, which may be a challenge in standardizing the Li levels in final food products obtained from such mushrooms. Further biomedical investigations, including experimental in vitro and in vivo models, are necessary to evaluate the medical potential of Li-enriched mushrooms.

In summary, the present study evaluated whether three commercially important mushroom species may be used in $\mathrm{Li}$ biofortification in order to produce $\mathrm{Li}$-enriched fruiting bodies. Apart from investigating the $\mathrm{Li}$ accumulation, its effect on the mycelium colony and the biomass of fruiting bodies was also assessed. The most promising effects were obtained for G. lucidum, both in terms of growth and in terms of $\mathrm{Li}$ accumulation. The adoption of this species may be particularly interesting in increasing the dietary intakes of Li for mood modulation purposes, given its already established medicinal status. Mushrooms biofortified with $\mathrm{Li}$ may find their use in decreasing rates of aggressive behaviors-a hypothesis yet to be tested in randomized control trials preceded by safety evaluations.

Funding Piotr Rzymski was supported by the Foundation for Polish Science within the "Start" Program (091.2016).

\section{Compliance with ethical standards}

Conflict of interest None of authors have a conflict of interest.

Ethical approval This article does not contain any studies with human participants or animals performed by any of the authors.

Compliance with ethics requirements This article doe not contain any studies with human or animal subjects.

Open Access This article is distributed under the terms of the Creative Commons Attribution 4.0 International License (http://creativecommons.org/licenses/by/4.0/), which permits unrestricted use, distribution, and reproduction in any medium, provided you give appropriate credit to the original author(s) and the source, provide a link to the Creative Commons license, and indicate if changes were made.

\section{References}

1. Lloyd L, Giaroli G, Taylor D, Tracy D (2011) Bipolar depression: clinically missed, pharmacologically mismanaged. Ther Adv Psychopharmacol 1:153-162

2. Coppen A (2000) Lithium in unipolar depression and the prevention of suicide. J Clin Psychiatry 61:52-56

3. Geddes JR, Goodwin GM, Rendell J, Azorin JM, Cipriani A, Ostacher MJ, Morriss R, Alder N, Juszczaj E (2010) Lithium plus valproate combination therapy versus monotherapy for relapse prevention in bipolar I disorder (BALANCE): a randomised open-label trial. Lancet 375:385-395

4. Shafti S (2010) Olanzapine versus lithium in management of acute mania. J Affect Disord 122:273-276

5. Cipriani A, Pretty H, Hawton K, Geddes J (2005) Lithium in the prevention of suicidal behavior and all-cause mortality in patients with mood disorders: a systematic review of randomized trials. Am J Psychiatry 162:1805-1819

6. Jones R, Arlidge J, Gillham R, Reagu S, van den Bree M, Taylor $P$ (2011) Efficacy of mood stabilisers in the treatment of impulsive or repetitive aggression: systematic review and meta-analysis. Br J Psychiatry 198:93-98

7. Campbell M, Adams PB, Small AM, Kafantaris V, Silva RR, Shell J, Perry R, Overall JE (1995) Lithium in hospitalized aggressive children with conduct disorder: a double-blind and placebo-controlled study. J Am Acad Child Adolesc Psychiatry 34:445-453

8. Yeh HL, Tsai SJ (2008) Lithium may be useful in the prevention of Alzheimer's disease in individuals at risk of presenile familial Alzheimer's disease. Med Hypotheses 71:948-951 
9. Goldstein MR, Mascitelli L (2016) Is violence in part a lithium deficiency state? Med Hypotheses 89:40-42

10. Marshall TM (2015) Lithium as a nutrient. J Am Phys Surg 20:104-109

11. Terao $\mathrm{T}$ (2015) Is lithium potentially a trace element? World $\mathbf{J}$ Psychiatry 5:1-3

12. Brown KM, Tracy DK (2013) Lithium: the pharmacodynamic actions of the amazing ion. Ther Adv Psychopharmacol 3:163-176

13. Freitas MD, Leverson BD, Goossens JL (2016) Lithium in medicine: mechanisms of action. Met Ions Life Sci 16:557-584

14. Schrauzer GN (2002) Lithium: occurrence, dietary intakes, nutritional essentiality. J Am Coll Nutr 21:14-21

15. Jathar VS, Pendharkar PR, Pandey VK, Raut SJ, Doongaji DR, Bharucha MP, Satoskar RS (1980) Manic depressive psychosis in India and the possible role of lithium as a natural prophylactic. II-Lithium content of diet and some biological fluids in Indian subjects. J Postgrad Med 26:39-44

16. Schrauzer GN, Shrestha KP (1990) Lithium in drinking water and the incidences of crimes, suicides, and arrests related to drug addictions. Biol Trace Elem Res 25:105-113

17. Desai G, Chaturvedi SK (2009) Lithium in drinking water and food, and risk of suicide. Br J Psychiatry 195:271

18. Giannaccini G, Betti L, Palego L, Mascia G, Schmid L, Lanza M, Mela A, Fabbrini L, Biondi L, Lucacchini A (2012) The trace element content of top-soil and wild edible mushroom samples collected in Tuscany, Italy. Environ Monit Assess 184:7585-7679

19. Vetter J (2005) Lithium content of some common edible wildgrowing mushrooms. Food Chem 90:31-37

20. Siwulski M, Mleczek M, Rzymski P, Budka A, Jasińska A, Niedzielski P, Kalač P, Gąsecka M, Budzyńska S, Mikołajczak P (2016) Screening the multi-element content of Pleurotus mushroom species using inductively coupled plasma optical emission spectrometer (ICP-OES). Food Anal Method. doi:10.1007/ s12161-016-0608-1

21. Niedzielski P, Mleczek M, Siwulski M, Gąsecka M, Kozak L (2015) Supplementation of cultivated mushroom species with selenium: bioaccumulation and speciation study. Eur Food Res Technol 241:419-426

22. Rzymski P, Mleczek M, Niedzielski P, Siwulski M, Gąsecka M (2016) Potential of cultivated Ganoderma lucidum mushrooms for the production of supplements enriched with essential elements. J Food Sci 81:587-592

23. Rzymski P, Mleczek M, Niedzielski P, Siwulski M, Gąsecka M (2016) Cultivation of Agaricus bisporus enriched with selenium, zinc and copper. J Sci Food Agric. doi:10.1002/jsfa.7816

24. Mleczek M, Niedzielski P, Kalač P, Siwulski M, Rzymski P, Gąsecka M (2015) Levels of platinum group elements and rareearth elements in wild mushroom species growing in Poland. Food Addit Contam Part A 33:86-94

25. Kalač P (2013) A review of chemical composition and nutritional value of wild-growing and cultivated mushrooms. J Sci Food Agric 93:209-218

26. Chang ST, Wasser SP (2012) The role of culinary-medicinal mushrooms on human welfare with a pyramid model for human health. Int J Med Mushrooms 14:95-134

27. Valverde ME, Hernández-Pérez T, Paredes-López O (2015) Edible mushrooms: improving human health and promoting quality life. Int J Microbiol 2015:376-387
28. de Assunção LS, da Luz JM, da Silva MDC, Vieira PA, Bazzolli DM, Vanetti MC, Kasuya MC (2012) Enrichment of mushrooms: an interesting strategy for the acquisition of lithium. Food Chem 134:1123-1127

29. Bishop KS, Kao CH, Xu Y, Glucina MP, Paterson RR, Ferguson LR (2015) From 2000 years of Ganoderma lucidum to recent developments in nutraceuticals. Phytochemistry 114:56-65

30. Jaworska G, Pogoń K, Bernaś E, Duda-Chodak A (2015) Nutraceuticals and antioxidant activity of prepared for consumption commercial mushrooms Agaricus bisporus and Pleurotus ostreatus. J Food Qual 38:111-122

31. Gil-Ramírez A, Soler-Rivas C, Rodriguez-Casado A, Ruiz-Rodríguez RG, Marín FR (2015) Effect of selenium-enriched Agaricus bisporus (higher Basidiomycetes) extracts, obtained by pressurized water extraction, on the expression of cholesterol homeostasis related genes by low-density array. Int J Med Mushrooms 17:105-116

32. Schrauzer GN, de Vroey E (1994) Effects of nutritional lithium supplementation on mood. A placebo-controlled study with former drug users. Biol Trace Elem Res 40:89-101

33. Klemfuss H, Schrauzer GN (1995) Effects of nutritional lithium deficiency on behavior in rats. Biol Trace Elem Res 48:131-139

34. Nestel P, Bouis HE, Meenakshi JV, Pfeiffer W (2006) Biofortification of staple food crops. J Nutr 136:1064-1067

35. Nunes MD, Cardoso WL, Luz JMR, Kasuya MCM (2015) Effects of lithium compounds on the growth of white rot fungi. Afr J Microbiol Res 9:1954-1959

36. Berger A, Rein D, Kratky E, Monnard I, Hajjaj H, Meirim I, Piguet-Welsch C, Hauser J, Mace K, Niederberger P (2004) Cholesterol-lowering properties of Ganoderma lucidum in vitro, ex vivo, and in hamsters and minipigs. Lipids Health Dis 3:2

37. Delzenne NM, Bindels LB (2015) Gut microbiota: Ganoderma lucidum, a new prebiotic agent to treat obesity? Nat Rev Gastroenterol Hepatol 12:553-554

38. Ma HT, Hsieh JF, Chen ST (2015) Anti-diabetic effects of Ganoderma lucidum. Phytochemistry 114:109-113

39. Li J, Zhang J, Chen H, Chen X, Lan J, Liu C (2013) Complete mitochondrial genome of the medicinal mushroom Ganoderma lucidum. PLoS ONE 8:e72038

40. Young W (2009) Review of lithium effects on brain and blood. Cell Transpl 18:951-975

41. Kalač P, Svoboda L (2000) A review of trace element concentrations in edible mushrooms. Food Chem 69:273-281

42. Sartori HE (1986) Lithium orotate in the treatment of alcoholism and related conditions. Alcohol 3:97-100

43. Młyniec K, Davies CL, de Agüero Sánchez IG, Pytka K, Budziszewska B, Nowak G (2014) Essential elements in depression and anxiety. Part I Pharmacol Rep 66:534-544

44. Vestergaard P, Licht RW, Brodersen A, Rasmussen NA, Christensen H, Arngrim T, Grønvall B, Kristensen E, Poulstrup I (1998) Outcome of lithium prophylaxis: a prospective followup of affective disorder patients assigned to high and low serum lithium levels. Acta Psychiatr Scand 98:310-315

45. Vita A, De Peri L, Sacchetti E (2015) Lithium in drinking water and suicide prevention: a review of the evidence. Int Clin Psychopharmacol 30:1-5 